\title{
Francis Harry Compton Crick \\ - DNA, o puzzle 3D -
}

\author{
Raquel Gonçalves Maia \\ Departamento de Química e Bioquímica, Faculdade de Ciências da Universidade de Lisboa \\ rmcgonc@gmail.com
}

\begin{abstract}
Francis Harry Compton Crick - DNA, a 3D puzzle - One night in October 1962, coming from the 1920 building in Portugal Place, Cambridge, England, a quiet place with a golden helix hanging over the door, the noise alarmed the neighbourhood - fireworks, bottles of champagne and the strident laughter of friends in party. They celebrated the award of the Nobel Prize in Physiology or Medicine to Francis Crick, in partnership with James Watson and Maurice Wilkins, "for their discoveries concerning the molecular structure of nucleic acids and its significance for information transfer in living material". Francis Crick liked to unravel secrets of life, molecular puzzles. The first secret was revealed. Other challenges followed. Crick confronted the genetic code, the relation of DNA and RNA, and together with proteins, its chemistry, biochemistry, biology.
\end{abstract}

Throughout his life, Francis Crick wonders. Is it possible to create life in the interstellar medium? And convey it through space by intelligent message? And what do we know about human consciousness? Neurobiology.

Francis Crick was special. His intelligence, his vigour, his intellectual charm, his discipline of thought explain the results he obtained and those of many others submitted to his annoying questioning.

$\mathrm{N}$ cato com uma hélice dourada pendurada sobre a porta, o barulho alarmou a vizinhança - fogo de artifício, garrafas de champanhe e os risos estridentes de amigos em festa. Celebrava-se a outorga do Prémio Nobel da Fisiologia ou Medicina a Francis Crick, em partilha com James Watson e Maurice Wilkins, "pelas suas descobertas sobre a estrutura molecular dos ácidos nucleicos e o seu significado para a transferência de informação na matéria viva". Francis Crick gostava de desvendar segredos da vida, puzzles moleculares. O primeiro segredo estava revelado. Outros desafios se seguiram. Crick enfrentou o código genético, a relação do DNA e do RNA, entre si e com as proteínas, a sua química, bioquímica, biologia.

Ao longo da vida, Francis Crick interroga-se. Será possível criar vida no meio interestelar? E transportá-la através do espaço por mensagem inteligente? E que sabemos nós sobre a consciência humana? Neurobiologia.

Francis Crick era especial. A sua inteligência, o seu vigor, o seu encanto intelectivo, a sua disciplina de pensamento explicam os resultados que ele obteve e os de muitos outros submetidos ao seu irritante questionar.

\section{Explosivos e explosões}

Os pais de Francis Harry Compton Crick foram Harry Crick e Annie Elizabeth Wilkins (Crick). O rapaz nasceu em 8 de junho de 1916 e foi o primeiro filho do casal. A mãe tinha então 37 anos e o pai era cerca de oito anos mais novo. Anthony (Tony) Foster Crick veio ao mundo dois anos depois. Os irmãos foram grandes companheiros na infância. A casa de família chamava-se "Holmgarth" e situava-se em Weston Favell, no condado de Northampton muito conceituado pelo fabrico de calçado e outras indústrias coureiras da Inglaterra. Os Crick e os Wilkins dispunham de uma excelente reputação de comerciantes vinda de várias gerações.

O ambiente familiar prezava a boa educação e movimentava-se entre a casa, os serviços religiosos e as representações teatrais no Royal Theatre de Northampton. Francis nunca esqueceu a arte dramática, e dela veio a fazer bom uso nas suas palestras públicas.

A verdadeira "casa de Francis", todavia, era a garagem de um automóvel que nunca existiu. Nela entravam produtos diversos e saíam os correspondentes rolos de fumo e

Professora Catedrática aposentada

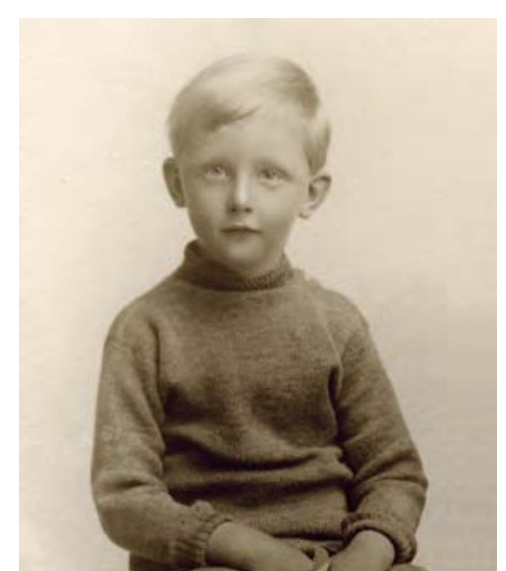

Figura 1 - Francis Crick, com 5 anos de idade. Cortesia da Família Crick.

explosões. Cedo, porém, Francis aprendeu a fazer explodir garrafas com misturas de substâncias químicas através de circuitos elétricos que manipulava à distância. Esta criatividade foi um passo útil para, em plena Segunda Guerra Mundial, fabricar muitos e variados circuitos que combinavam sensores magnéticos e acústicos para ativar bombas submersas no oceano [1-3]. 
“Can chemistry build up life?”, lia-se numa enciclopédia infantil que os pais lhe ofereceram. Francis ficou em êxtase. Segundo ele, terá sido a enciclopédia e a sua primeira professora, Miss Holding, que "tornava tudo interessante”, que o levaram a ser cientista. O seu fascínio começava no átomo e prolongava-se até aos confins do universo.

\section{Eterno estudante}

Francis frequentou a Northampton Grammar School e, em Londres, a Mill Hill School. Uma aprendizagem desinteressante conduziu-o ao fracasso nos exames de admissão à Universidade de Cambridge. Em alternativa, ingressou no University College London - UCL, à época uma escola pouco reputada, com uma investigação científica incipiente. Francis Crick terminou o curso de física, em 1937, com um resultado modesto; seguiu-se a pós-graduação com vista a doutoramento. Apesar do tema - variação da viscosidade da água com a temperatura - ser pouco estimulante face ao entusiástico momento que a física atravessava, Crick empenhou-se na pesquisa. Em 1940, porém, a guerra fecha as portas dos laboratórios da UCL e, em 1941, uma das bombas lançadas sobre Londres destrói o dispositivo experimental de Crick.

Decorrem cinco anos em que Crick trabalha para o "esforço de guerra" no Almirantado, integrado num grupo de excelência, o Mine Design, no laboratório de investigação naval. Em pouco tempo, o grupo cria minas magnéticas e óticas, com diferenciação permanente dos circuitos híbridos de ativação; só Crick forneceu 100 diferentes circuitos.

Terminada a guerra, Francis teve a certeza que o seu futuro passava pela investigação fundamental, que não mais queria trabalhar para fins de destruição. Contudo, já não era a física que o entusiasmava, antes a química e a biologia, os átomos e as moléculas. Queria começar tudo de novo. Acresce que Francis Crick casara em 1936 com Ruth Doreen Dodd, de quem teve um filho, Michael, em 1940. Em 1946 o casamento acaba em divórcio, tendo o pequeno passado a viver com os avós paternos. Francis visitava o filho amiúde e escrevia-lhe com frequência, mas era um "homem livre”. Tinha 31 anos, “velho” demais para os padrões sociais de um estudante. Mas Francis jamais se submetia a normas convencionais.

Foi o laboratório biomédico The Strangeways Research Laboratory, em Cambridge, que lhe abriu as portas à investigação [4]. O programa de trabalho envolvia o estudo

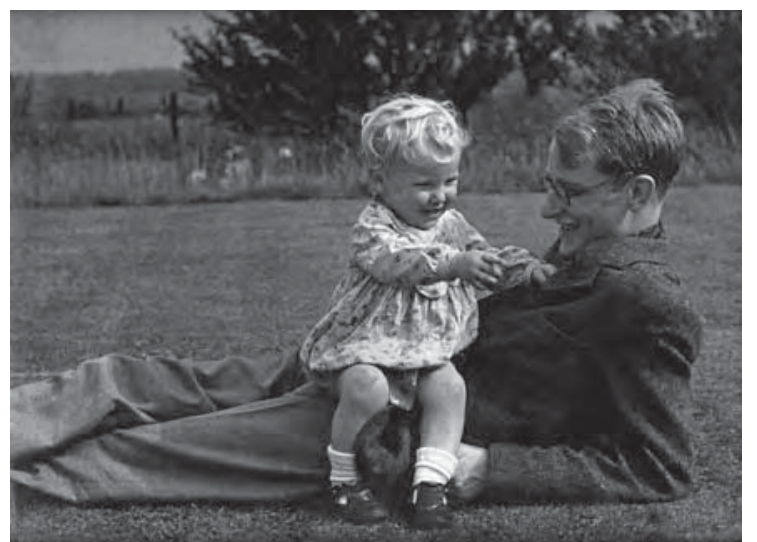

Figura 2 - Francis Crick com o filho Michael (1941). Cortesia da Família Crick. do movimento de partículas no interior de células vivas por ação de um campo magnético, com o fim de inferir a natureza do conteúdo semi-líquido das células. As expectativas de conseguir obter um doutoramento eram nulas ou quase nulas. Crick, porém, aceitou; por agora.

Entretanto, casara com Odile Speed - um casamento civil, um par muito elegante, família e amigos. A relação entre eles durou até ao fim das suas vidas. Duas filhas, Gabrielle Anne e Jacqueline Marie-Therese, presentearam este encontro.

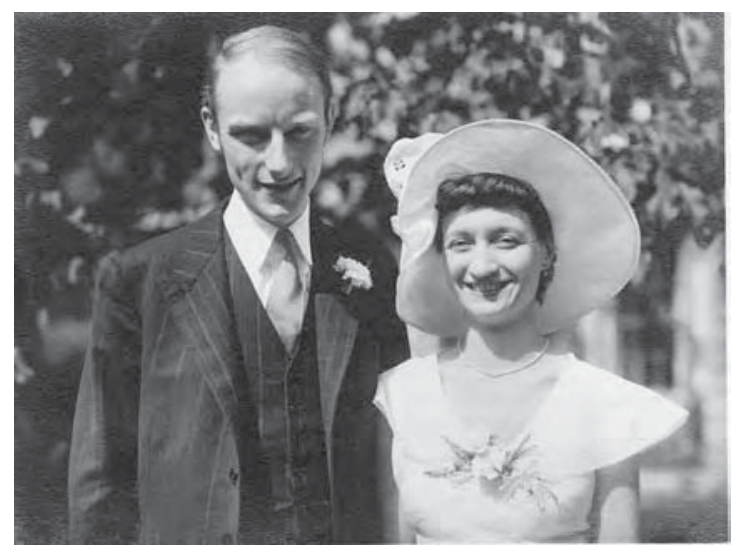

Figura 3 - Francis Crick e Odile Speed no dia do seu casamento (1949). Cortesia da Família Crick.

Em meados de 1949, Francis Crick transita para a MRC Unit for Molecular Biology, onde reinam as proteínas e a cristalografia de raios X. As entrevistas com Lawrence Bragg (1890-1971; Prémio Nobel da Física em 1915), o temido Cavendish Professor, e com Max Perutz (1914-2002; Prémio Nobel da Química em 1962), correram bem. Bragg foi cauteloso, mas Perutz efusivo: “[Crick] é excepcionalmente inteligente, com um vivo interesse, uma clara mente analítica e uma capacidade para detetar rapidamente a essência de qualquer problema”. Solicitou-se a Crick que se aplicasse na obtenção do doutoramento, tendo Perutz por supervisor [5,6].

À terceira era mesmo a sério... mas não se pedisse a Francis Crick que cumprisse um horário, nem que dispensasse acaloradas discussões sobre as investigações em curso na MRC Unit. A dissertação doutoral de F.H. Compton Crick, assim a assinou, "Polypeptides and Proteins: $X$-Ray Studies”, foi apresentada no verão de 1953. Sem esconder as limitações dos resultados experimentais, a tese oferece inovação metodológica na interpretação dos diagramas de difração de raios X. Em anexo, Crick acoplou os seus artigos já publicados. Dois deles referiam-se à revelação da estrutura do DNA. Finalmente, Dr. Francis Crick ganhara o almejado estatuto académico.

Revelação da estrutura do DNA... Como e quando aconteceu?

\section{A descoberta do DNA}

A molécula que hoje conhecemos pela famosa sigla DNA (ou ADN), o ácido desoxirribonucleico, foi identificada nos anos sessenta do século XIX pelo médico e biólogo suíço Friedrich Miescher (1844-1895). Chamou-lhe “nucleína”. Por volta de 1881, o bioquímico alemão Albrecht Kossel (1853-1927; Prémio Nobel da Fisiologia 
ou Medicina em 1910) determinou a composição química dos ácidos nucleicos DNA e RNA: bases, açúcar e grupos fosfato. Isolou as cinco bases presentes nos ácidos: adenina (A), citosina (C), guanina (G), timina (T) e uracilo (U). Numa outra vertente de investigação, Walther Flemming (1843-1905), médico e biólogo alemão, descobriu que existia no núcleo da célula uma substância fibrosa que ele denominou de “cromatina”, os cromossomas; estes, separavam-se durante a mitose. Posteriormente, Walter Sutton (1877-1916), geneticista norte-americano, e Theodor Boveri (1862-1915), biólogo alemão, independentemente, afirmaram que o material genético estava no interior dos cromossomas.

Oswald Avery (1877-1955), de origem canadiana e nacionalidade americana, em colaboração com Colin MacLeod (1909-1972) e Maclyn McCarty (1911-2005) identificaram o "princípio transformador”; na publicação dos resultados, em 1944, afirmam que é o DNA, e não as proteínas como se acreditava ao tempo, o material hereditário nas bactérias e sugerem que o mesmo poderá acontecer com os organismos superiores [7]. Erwin Chargaff (1905-2002), bioquímico de origem austro-húngara refugiado nos EUA, seduzido pelas conclusões de Avery, trabalhou sobre os ácidos nucleicos. Em 1950, fez uma descoberta que será determinante na decifração da estrutura 3D do DNA. No DNA, as bases não apareciam, todas, em igual abundância, mas as quantidades de A e T eram iguais entre si, dentro da margem de erro experimental, assim como as de G e C. Eis a "primeira regra de Chargaff”. Uma segunda regra foi também deduzida: a composição do DNA varia de espécie para espécie, mas em acordo com a primeira regra. A diversidade por espécie e a paridade das bases chamaram a atenção de investigadores que começaram a olhar o DNA como um credível candidato a material genético.

\section{A revelação 3D do DNA}

O jovem norte-americano James Watson (n. 1928), com o seu estranho corte de cabelo "crew cut", chega a Cambridge em outubro de 1951. Tinha 23 anos e propunha-se completar um pós-doutoramento iniciado na Universidade de Copenhaga. Era licenciado em zoologia e doutorado em genética do mundo dos fagos. Conhecera Maurice Wilkins (1916-2004), investigador no King's College, London, num congresso em Nápoles; uma “desfocada” fotografia de difração de raios X de DNA cristalizado que este apresentara deixara Watson em estado de pura surpresa e excitação.

No King's College, além de Maurice Wilkins, trabalhava a "alarmingly clever" cientista Rosalind Franklin (1920-1958) [8] no desvendar da estrutura do DNA, ambos no grupo do eminente físico John Randall (1905-1984). Francis Crick era amigo de Wilkins e, crente que o segredo da vida se encontraria na estrutura-função das proteínas, instigava-o a abandonar pesquisas sobre os ácidos nucleicos. Contudo, além-mar, o célebre Linus Pauling (Prémio Nobel da Química em 1954; Prémio Nobel da Paz em 1962) começava igualmente a interessar-se pela estrutura do DNA.

Sobre o primeiro encontro com Crick, no Laboratório Cavendish, dirá Watson que se deu um "instantaneous meeting of minds”. Apesar da diferença de idades, Crick e
Watson tinham em comum uma "arrogância e truculência juvenis”, uma impaciência que produzia um pensamento e um discurso permanentemente “à solta”. Jim fez Francis mudar de ideias sobre o DNA.

Crick propõe estudarem o DNA segundo a metodologia de Pauling. Construiriam modelos moleculares, com direções e comprimentos das ligações a preceito. A criação de tais modelos diminuiria o número de possibilidades estruturais que os diagramas de difração de raios $\mathrm{X}$ admitem. Não fora assim que Pauling descobrira a estrutura em "hélice $\alpha$ " das proteínas? Que grande triunfo seria derrotar Pauling no seu próprio domínio! Não fariam experiências, antes analisariam dados obtidos por outros.

Alguns diagramas faziam prever que a estrutura do DNA fosse helicoidal; outros não. A dúvida provinha da utilização de cristais de DNA seco, A-DNA, e de cristais hidratados, B-DNA, forma mais distendida e de menor diâmetro. Rosalind Franklin, com uma perícia inigualável, conseguira obter diagramas das duas formas, separadas, com grande nitidez. As imagens do B-DNA, com o seu X central, era sinal claro da existência de estrutura em hélice, assim informara no King's College o perito em física-matemática Alexander Stokes (1919-2003) [9].

Como encaixar, então, as diferentes peças do puzzle as bases A, C, G e T, a pentose desoxirribose e os grupos fosfato - de forma a criar um modelo estrutural do DNA?

Sucedem-se as animadas conversas entre Francis e Jim, que não se confinam ao Laboratório Cavendish, antes se prolongam pelas ruas de Cambridge, pelo almoço no pub "The Eagle" que eles ajudaram a celebrizar, pelos passeios na margem do rio Cam, pelos longos jantares que Odile Crick lhes proporciona.

Com placas de metal e arames, eis que Crick e Watson criam a "estrutura mais provável” para o DNA: uma disposição helicoidal de três cadeias, com os esqueletos de açúcar-fosfato no interior e as bases viradas para o exterior. Estamos em finais de 1951. Crick telefona a Wilkins. Instalado o pânico no King’s College, não só Wilkins, mas também Franklin, voam de Oxford para Cambridge. Crick ainda começa um discurso, mas o primeiro olhar de Rosalind Franklin vai reduzi-lo ao silêncio. De forma resumida, diremos apenas que os grupos fosfato teriam de estar virados para o exterior da molécula - ou o ácido DNA não seria ácido...

E a polémica estala. Mas não era no King’s College que se investigava a estrutura do DNA? O resultado imediato foi Maurice admoestar Francis e Bragg pedir desculpa a Randall. Crick trabalharia na sua tese, e só na sua tese. Jim Watson permaneceu livre. Aparentemente, nada mais se passara do que uma "abordagem infantil".

Decorre o ano de 1952. O King's College permanece em silêncio. Em vésperas de Natal, o filho de Linus Pauling, Peter Pauling, a trabalhar no Laboratório Cavendish, anuncia que o pai decifrara a estrutura do DNA.

Um soco no estômago! Watson mantinha contato com Wilkins e Crick continuava com o DNA presente no espírito. Quando, em janeiro de 1953, Crick e Watson tiveram oportunidade de ler o manuscrito de Linus Pauling respiraram de alívio; Pauling cometera erros de "principiante" semelhantes aos seus - era quimicamente impossível um empacotamento tão retorcido e, para mais, o DNA não 
seria ácido! Também Maurice respirou de alívio. E o que pensaria Rosalind? Difícil de imaginar. Já há muito que dispunha da explícita "Fotografia 51” e de imensa informação relevante [10]. Em Londres, mas também em Cambridge, não mais era possível travar o sprint pelo DNA.

Watson opta por duas cadeias, intui que as bases estabelecem ligações de hidrogénio entre si, pares de bases! Usa a forma cetónica, mais estável, por sugestão de Jerry Donohue (1920-1985), o norte-americano que trabalhara com Pauling. Sem perder tempo, recorta em cartão os polígonos que serão as bases. A fazia par com T e C com G. Crick observa, põe em marcha o seu poder de visualização tridimensional, lembra as regras de Chargaff e as características da célula unitária. Aprova plenamente. Durante o almoço, no "The Eagle", anunciou bem alto que tinham descoberto o segredo da vida.

Muito metal galvanizado e muito tubo saiu, "a régua e esquadro”, da máquina do Cavendish. A montagem do puzzle 3D do DNA foi terminada no dia 7 de março. No dia 12, frente ao modelo helicoidal, Wilkins a custo ultrapassou o seu desânimo. A estrutura era bonita demais para estar errada...

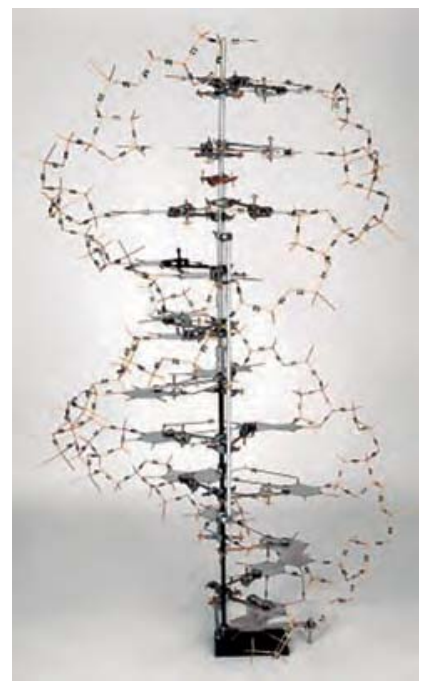

(C) MRC Laboratory of Molecular Biology

Figura 4 - Reprodução do modelo do DNA de Crick e Watson (1953).

Bragg, Randall e o editor da revista Nature negociaram a sua apresentação: três artigos, em páginas consecutivas, o primeiro vindo do Laboratório Cavendish e os seguintes do King's College. No dia 25 de abril de 1953, no n. ${ }^{\circ}$ 171, a Nature exibia: “A Structure for Deoxyribose Nucleic Acid”, por J.D. Watson e F.H.C. Crick; "Molecular Structure of Deoxypentose Nucleic Acids”, por M.H.F. Wilkins, A.R. Stokes e H.R. Wilson e "Molecular Configuration in Sodium Thymonucleate”, por R. Franklin e R.G. Gosling [10]. No primeiro artigo descreve-se a estrutura em dupla hélice do DNA, acompanhado de um esquema muito simples que foi desenhado por Odile Crick. É dito que "a estrutura sugere um possível mecanismo de cópia para o material genético”.

\section{O sucesso}

Por muito importante que a descoberta da estrutura espacial do DNA seja, no imediato, ninguém parece ter-lhe dado o merecido realce. Francis Crick dirá que para o modelo passar de "bastante plausível” a "muito plausível” e, finalmente, a "virtualmente certamente correto" foi necessário um quarto de século.

Crick, porém, contou bem cedo com um profundo admirador: seu filho Michael. Em 17 de março de 1953, Crick escreveu a Michael, então com 12 anos. "Jim e eu fizemos provavelmente uma descoberta muito importante. [...] Acreditamos que o DNA é um código”. E, com o auxílio de um esquema, explica ao filho como a Natureza é capaz de fazer cópias de genes, como a vida nasce da vida... Muito anos depois, em 2015, a artista e bióloga molecular Kindra Crick (n. 1976), filha de Michael Crick e neta de Francis Crick, elaborou a obra "What Mad Pursuit”, inspirada na dupla hélice [11]. Nela incorporou as cadeias do DNA, tal como desenhadas por seu avô na célebre carta enviada a Michael. A escultura pertence, na atualidade, à coleção permanente do Laboratory of Molecular Biology.

Em 1962, a MRC Unit deu lugar ao MRC Laboratory of Molecular Biology - LMB. Edifício novo, espaços novos, tendo Max Perutz por chairman e Francis Crick na direção da linha de pesquisa "Genética Molecular”. Nesse ano, o Prémio Nobel da Fisiologia ou Medicina, "pelas suas descobertas sobre a estrutura molecular dos ácidos nucleicos e o seu significado para a transferência de informação na matéria viva”, foi partilhado por Francis Crick, James Watson e Maurice Wilkins. Desde 1961 que a casa de Francis Crick, em Portugal Place, fora ornamentada com uma hélice simples pintada de dourado. A casa passara a denominar-se "Golden Helix".
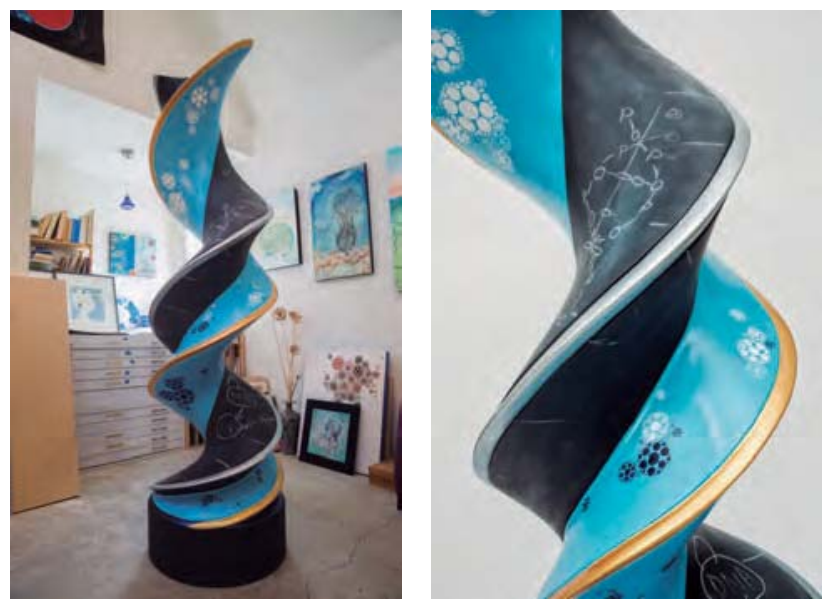

Figura 5 - "What Mad Pursuit", escultura de Kindra Crick. Cortesia de Kindra Crick. 


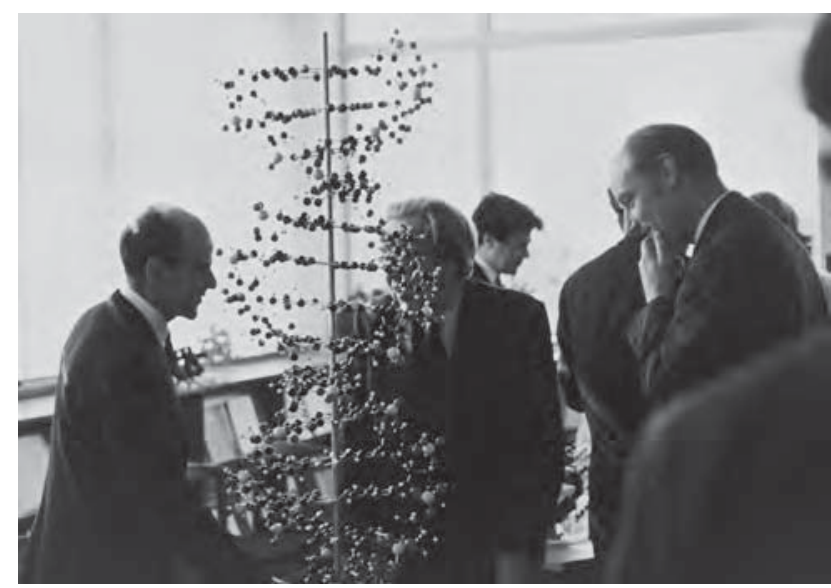

(C) MRC Laboratory of Molecular Biology

Figura 6 - Max Perutz, Desmond Bernal e Francis Crick rodeiam um modelo do DNA. Abertura do Laboratory of Molecular Biology (1962).

\section{To do, or die; or don't try}

Em 1953, Francis Crick, sua mulher e filhos rumam aos EUA. Crick aceitara o convite do cientista David Harker (1906-1991) para trabalhar durante um ano no seu grupo de pesquisa estrutural de proteínas por cristalografia de raios X, no Brooklyn Polytechnic. Não correu bem, a estratégia do estudo não agradou a Francis. Mas viajou, discursou sobre o DNA, maravilhou-se com a Califórnia e reuniu-se a James Watson e a George Gamow (1904-1968) com a ideia firme de enfrentar o código genético. Crick acreditava que o DNA "fabricava” as proteínas e Watson recomendava a intermediação do RNA.

O "RNA Tie Club" constitui-se em 1954. Fundado por Watson e Gamow, incluía um conjunto de 20 cientistas - tantos quanto os aminoácidos, com o fim de "resolver o enigma do RNA", com o lema "to do, or die; or don't try". Watson era o PRO (prolina), com a designação oficial de "otimista”, Gamow o ALA (alanina), "sintetizador", e Crick o TYR (tirosina), "pessimista". Os membros tinham encontros semestrais, onde fluíam as ideias criadoras, os cigarros e o álcool. Todos os seus membros foram personalidades de destaque no meio científico.

Crick regressa ao Cavendish, o seu interesse agora dirigido para os genes. Em Sydney Brenner (n. 1927; Prémio Nobel da Fisiologia ou Medicina em 2002), bioquímico nascido na África do Sul, encontra um novo parceiro de discussão. É ele quem sugere a Francis a existência de "adaptadores" na produção de proteínas. Antes da ligação peptídica, os aminoácidos seriam enzimaticamente ligados a pequenas moléculas, os "adaptadores”, que teriam superfícies especificamente desenhadas para ligar tripletos de ácidos nucléicos. Interessante.

Crick investiu as suas capacidades intelectivas na sistematização do processo de "tradução" do DNA em proteínas, tendo em conta o que era teórica e experimentalmente reconhecido e o que era apenas opinião. A partir daí deduziu a sua própria predição - o que foi apresentado em dois artigos memoráveis intitulados "On Protein Synthesis" (1958) e "General Nature of the Genetic Code for Proteins” (1961) [12,13].

\section{The Salk Institute}

Desde menino que Francis Crick interrogava a Vida. E, teórica e experimentalmente, foi revelando os seus segredos. Primeiro, a estrutura do DNA, depois a do código genético... Uma nova etapa iria começar na vida do cientista. Duas problemáticas vão merecer a sua especial atenção: a origem da vida, em consequência direta da origem do código genético, e a estrutura das células do sistema nervoso que acionam a informação e justificam o comportamento.

Nos anos 70, Francis Crick e o seu colega Leslie Orgel (1927-2007) propõem a "Panspermia Dirigida". Orgel era diretor do Laboratório de Evolução Química do The Salk Institute, em La Jolla, Califórnia, desde a sua fundação em 1964 e Crick era, então, "nonresident fellow" [14]. Crick e Orgel admitem a existência de uma sociedade tecnologicamente avançada algures noutro planeta. De forma deliberada, primitivas formas de vida teriam sido enviadas para a Terra por meio de naves espaciais não tripuladas. Acreditaria realmente Crick na sua hipótese de "Panspermia Dirigida”? Ou, como era seu hábito, fazia um exercício de imaginação, provocava o debate e alimentava novas pesquisas?

Crick tem 60 anos e a reforma próxima em Cambridge. Não quer abandonar a pesquisa, não deseja envolver-se em cargos administrativos. Ser Master de um College? Nunca!

Com Odile, troca Cambridge pela Califórnia, rendido à oportunidade de iniciar estudos sobre os mecanismos de perceção do cérebro e usufruir do Sol, do mar e do resplendor da luz no deserto. As filhas quedam-se pelo Reino Unido; o filho Michael, casado, vive em Seattle, nos EUA.

Uma "black box", assim é o cérebro, conclui Crick. Estamos muito longe dos átomos e das moléculas... Em 1994, Crick publica "The Astonishing Hypothesis: The Scientific Search for the Soul", onde foca a sua atenção no sistema de visão cerebral [15]. Ficou famosa a sua frase inicial: "You, your joys and your sorrows, your memories and ambitions, your sense of personal identity and free will, are in fact no more than the behavior of a vast assembly of nerve cells and their associated molecules." Estamos muito longe dos átomos e das moléculas... Estamos?

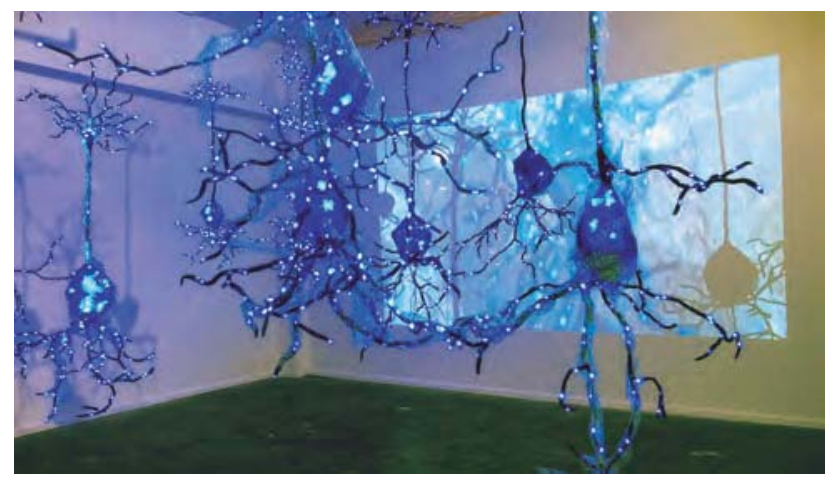

Figura 7 - "Your Joys, Sorrow, Memory and Ambition", instalação artística inspirada em neurociência, por Kindra Crick. Cortesia de Kindra Crick. 


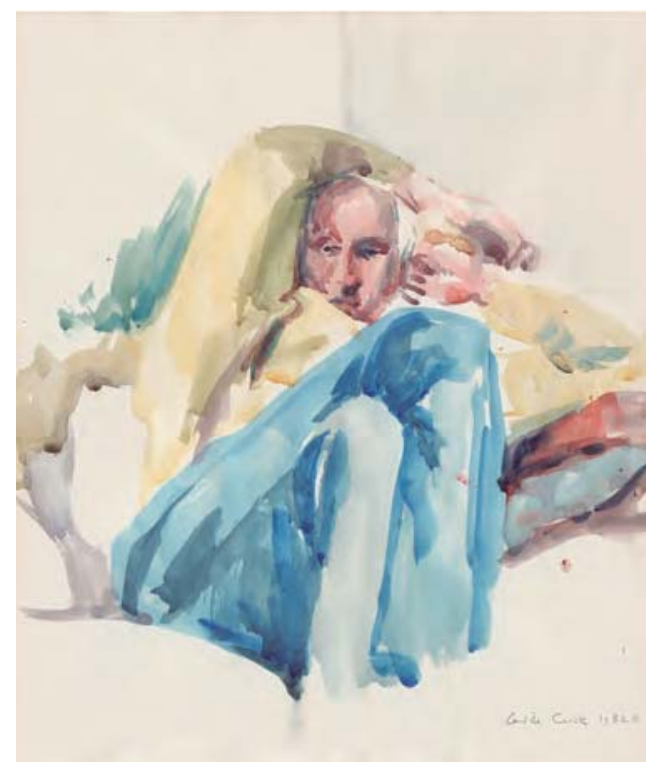

Figura 8 - “Francis Crick”, aguarela de Odile Crick (1982). Cortesia da Família Crick.

"Foi em seu convidativo escritório com vista para o Pacífico, ou à sombra da piscina em sua casa, que ele [Francis Crick] destilou ideias com Christof Koch e reuniu cientistas para trabalhar num dos maiores mistérios não resolvidos da ciência: a consciência. A sua busca era descobrir as correlações neurais da consciência - o circuito biológico que sensibiliza os animais. Tive a sorte de me juntar a ele durante as refeições com outros cientistas, durante as quais ele ouvia, fazia perguntas exploratórias e participava em intensos diálogos. Essas trocas eram um cadinho amigável para novas ideias, muitas vezes lançando os participantes em direções brilhantes e inesperadas. Lembro-me de cientistas que interagiram com ele que comentaram a sua capacidade de chegar ao cerne de um problema, a sua generosidade intelectual e o entusiasmo contagiante pela ciência. [Crick] foi uma inspiração e uma pedra-de-toque para aqueles que se apaixonaram por descobrir as respostas às questões mais fundamentais sobre a base biológica da vida e do pensamento" - palavras de Kindra Crick, tão elucidativas quanto emocionantes [16].

\section{Um homem singular}

Francis Crick era extrovertido e gregário, explosivo e afável; as suas gargalhadas estridentes, o seu antagonismo religioso e político impertinente e as excentricidades sociais incomodavam tradicionalistas. Lawrence Bragg começou por mostrar "tolerância zero" para com Crick; mas mudou de opinião. Em 1959, Crick foi eleito Fellow da Royal Society por proposta de Perutz e Bragg. Na recomendação, Bragg escreveu que Crick possuía "um espírito muito vivo, inteligente e especulativo".

A associação Watson-Crick levou a algumas confusões, nem sempre atraentes para Crick. Numa estada em Paris, Francis Crick dialogou com Jacques Monod (1910-1976) e François Jacob (1920-2013), que partilharam o Prémio Nobel da Fisiologia ou Medicina com André Lwoff. Esses dois brilhantes cientistas afirmaram, com espanto, que Crick não era “um apêndice de Watson”, longe disso! Mais tarde, Monod disse ainda: "Ninguém descobriu nem criou

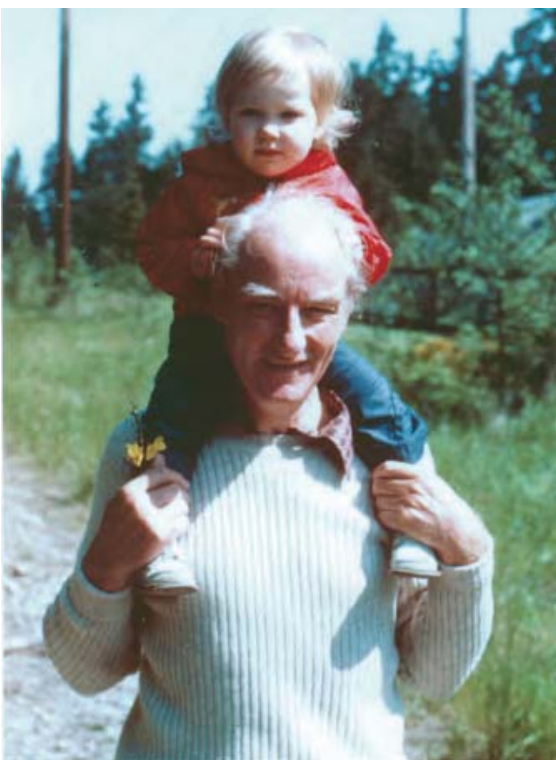

Figura 9 - Francis Crick com a neta Kindra, filha de Michael (1977).

a biologia molecular. Mas um homem [Francis Crick] domina intelectualmente toda esta área do conhecimento”.

Os desafios que lançava nasciam da sua preocupação com o futuro da humanidade, considerava que era tempo de enfrentar os tabus, as superstições, a ignorância. Muitas vezes excedeu-se. No trabalho científico, porém, sempre manteve a lucidez e a concentração. Recusou muitas honras e graus honoríficos, mas aceitou a Order of Merit, em 1991.

Em família, era um pai e marido presente, embora algo distante. Odile tinha o seu refúgio, afastado da ciência; montou um estúdio onde se dedicou a pintar e a esculpir.

Esteve seriamente doente em 1995, mas um bypass coronário e a substituição de uma parte da aorta permitiram a recuperação. Em 2001 foi-lhe diagnosticado cancro no cólon. Crick veio a falecer em julho de 2004, imerso em ideias e trabalho.

Francis Crick era especial. A maior homenagem que lhe foi feita terá sido, porventura, a atribuição do seu nome a um monumental instituto de investigação, nascido em 2016, no centro de Londres. The Francis Crick Institute dedica-se à biomedicina, à compreensão da biologia fundamental subjacente à saúde e à doença.

\section{Agradecimento}

À Família Crick e, em particular, a Kindra Crick, artista plástica e bióloga molecular, neta de Francis Crick, pela amável oferta de testemunhos pessoais e disponibilização de algumas das fotografias que ilustram este artigo.

\section{Referências}

[1] R. Olby, "Francis Crick: Hunter of Life's Secrets”, Cold Spring Harbor Laboratory Press, Nova Iorque, 2009.

[2] M. Ridley, "Francis Crick: Discoverer of the Genetic Code”, HarperCollins Publishers, Nova Iorque, 2009.

[3] R. Gonçalves-Maia, "Crick”, Série "Dos Átomos e das Moléculas”, n. ${ }^{\circ}$ 6, LF Editorial, São Paulo, em publicação.

[4] The Strangeways Research Laboratory foi fundado em 1905 pelo médico patologista Thomas Strangeways (1866-1926); a investigação nele desenvolvida centrava-se em aspetos clínicos, na cultura de tecidos e na biologia celular. 
[5] R. Gonçalves-Maia, "Perutz", Série "Dos Átomos e das Moléculas”, n. ${ }^{\circ}$ 5, LF Editorial, São Paulo, 2017.

[6] R. Gonçalves-Maia, QUÍMICA - Boletim SPQ 145 (2016) 117-122.

[7] O.T. Avery, C.M. MacLeod, M. McCarthy, J. Exp. Med. 79 (1944) 137-158.

[8] No dizer de uma sua tia paterna, Rosalind Franklin era uma menina "alarmingly clever" que, aos seis anos de idade, preferia resolver problemas de aritmética a brincar com bonecas.

[9] É justo citar o nome de Elwyn Beighton, a trabalhar na Universidade de Leeds no grupo de William Astbury (18981961). As suas fotografias de difração de raios X do DNA, obtidas em 1951, nunca publicadas em jornal científico, mostram uma semelhança notável com a "Fotografia 51" de Franklin. O significado de tal imagem não foi interpretado. Leeds poderia ter alterado o rumo da história.

[10] "Double Helix: 50 years of DNA", Nature 421 (2003). http://www.nature.com/nature/dna50/archive.html

[11] A exclamação “What Mad Pursuit” (“Que Busca Louca!”) pertence a um verso do poema "Ode on a Grecian Urn”, do grande poeta romântico britânico John Keats; foi utilizada por Crick como título de palestra e de livro.
[12] F.H.C. Crick, The Symposia of the Society for Experimental Biology 12 (1958) 138-163.

https://profiles.nlm.nih.gov/ps/retrieve/ResourceMetadata/ SCBBZY

[13] F.H.C. Crick, L. Barnett, S. Brenner, R.J. Watts-Tobin, Nature 192 (1961) 1227-1232. https://www.nature.com/ nature/journal/v192/n4809/pdf/1921227a0.pdf

[14] Em La Jolla erguera-se um edifício ultra-moderno, da autoria do arquiteto Louis Kahn, que albergava um instituto de pesquisa do futuro, de análise de "outras matérias fascinantes!” - o Salk Institute for Biological Studies - perfeito para Francis Crick. Era seu diretor Jonas Salk (1914-1995), o médico norte-americano que primeiro desenvolvera uma vacina contra a poliomielite.

[15] F. Crick, "The Astonishing Hypothesis: The Scientific Search for the Soul”, Scriber, Nova Iorque, 1995.

[16] Texto de Kindra Crick, que a própria adaptou para o livro da ref. [3], a partir de uma palestra que proferiu no simpósio “Celebrating Francis”, CSHL - Cold Spring Harbor Laboratory, 2016.

\section{Atualidades Científicas}

\section{Membranas de matriz mista para purificação de hidrogénio}

O uso de hidrogénio com elevado grau de pureza é importante em várias áreas. O método de purificação de $\mathrm{H}_{2}$ mais comum é a separação por membrana, que permite, nomeadamente, separar eficazmente misturas $\mathrm{H}_{2} / \mathrm{N}_{2}$. No entanto, o uso desta tecnologia tem sido mais desafiante para a separação de $\mathrm{H}_{2} / \mathrm{CO}_{2}$. As membranas de paládio são bastante eficientes para esta separação mas o seu custo impede a sua utilização em larga escala. Várias alternativas, que passam pelo design de novos polímeros, misturas poliméricas e membranas de matriz mista têm sido propostas para melhorar o desempenho da membrana seletiva de $\mathrm{H}_{2}$. Uma alternativa promissora é o uso de membranas de matriz mista incorporando nanopartículas de paládio.

Recentemente, investigadores da Universiti Sains Malaysia, Malásia, prepararam membranas de polibenzimidazol (PBI) com diferentes teores de nanopartículas de Pd estabilizadas com polietilenoglicol (PEG). Os autores aliaram a excelente estabilidade física, térmica e química da membrana de PBI, além da sua boa seletividade intrínseca para a separação $\mathrm{H}_{2} / \mathrm{CO}_{2}$, com a excelente capacidade intrínseca do Pd em separar os dois gases. A equipa sintetizou as nanopartículas de paládio usando $\mathrm{PdCl}_{2}$ como precursor de Pd e PEG como agente redutor e estabilizador. As nanopartículas foram então adicionadas ao polímero em solução, a mistura foi colocada sobre placas de vidro e o solvente evaporado. O material obtido permitiu uma seletividade para $\mathrm{H}_{2} / \mathrm{CO}_{2}$ de 18,6 a $200{ }^{\circ} \mathrm{C}$. Ao contrário das membranas de $\mathrm{Pd}$, as membranas de matriz mista estudadas começam a interagir com o $\mathrm{H}_{2}$ a temperaturas inferiores. Os resultados mostraram ainda que é necessária apenas uma pequena quantidade de nanopartículas de Pd para aumentar significativamente a seletividade de $\mathrm{H}_{2} / \mathrm{CO}_{2}$ em comparação com a das membranas de $\mathrm{PBI}$ puras.

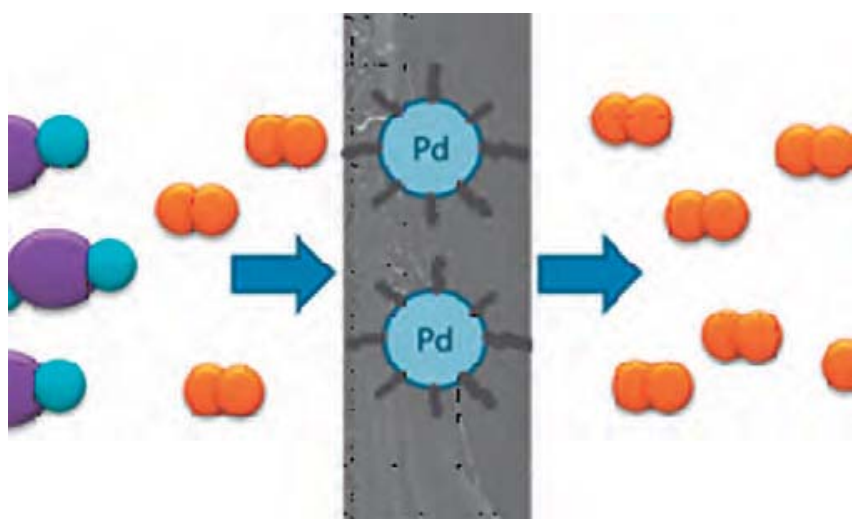

\section{Fontes:}

Mixed-matrix membranes for $\mathrm{H}_{2}$ purification, http:// www.chemistryviews.org/details/ezine/10490892/ Mixed-Matrix_Membranes_for_H2_Purification. html?elq_mid=16907\&elq_cid=3941189 (Acedido em 12/05/2017)

H.S.M. Suhaimi, C.P. Leo, A.L. Ahmad. Hydrogen purification using polybenzimidazole mixed-matrix membranes with stabilized palladium nanoparticles. Chem. Eng. Technol. 40 (2017) 631-638.

Paulo Mendes (pjgm@uevora.pt) 